\title{
INTEGRATING ARCHAEO-TOURISM WITH GEOTOURISM DEVELOPMENT IN BANTIMURUNG NATIONAL PARK, SOUTH SULAWESI PROVINCE
}

\author{
Hery Sigit Cahyadi \\ Bandung Institute of Tourism \\ Tourism Management Department \\ Bandung - Indonesia \\ herysigit@gmail.com \\ 081313837448
}

\begin{abstract}
Bantimurung Bulusaraung National Park is known with its pre-historic caves that is admitted as the eldest pre-historic caves in the world and base on the research its came from 40,000 thousand years ago. There are more than hundreds pre-historic caves in this national park. But the fact is not many people know that potential and uniqueness. People only know that area with its beautiful landscape and the place where the tourists can find the adventurous activities like rock climbing and caving. The prehistoric caves only like a dead museum without interpretation and no tourism development is conducted to attract visitors. As a cultural treasure, the prehistoric caves are not develop yet as an archaeological tourism and regarding on its potential it needs immediate development to preserve it and integrated to the tourism development that already there. The lack of coordination and cooperation between national park and heritage preservation board is the main problem why this potential attraction is not developed yet.

Qualitative data analysis and interview was conducted to visitors and local communities to find out their activities in national park areas.

The aim of this research is how to integrate the archaeological as tourist attraction into geotourism as main activities in Bantimurung Bulusaraung National Park.
\end{abstract}

Keywords: Archaeo-tourism, geotourism, Bantimurung National Park

\section{INTRODUCTION}

Bantimurung Bulusaraung National Park is the second largest and beautiful karst area in the world after China. The bunch of karst is located in two regencies, Maros and Pangkep Regencies with the large area of 43.750 ha. Its uniqueness can't find in another places in Indonesia. Maros - Pangkep Karst is not only about the row of rocks, tower karst, and caves but also has pre-historical value. There are 268 pre-historical caves in this karst area and admitted as the largest pre-historical complex in Asia that came from 39.000 BC.

The oldest pre-historic caves in the world. In the caves we can find pre historic paintings like arms, boats, people, anoa and wild boar. This place also well-known as the kingdom of butterflies. For years the National park has already known as its cliffs and natural caves for adventure activities, but not many people knows that the place also has another potential resources like pre-historic caves.

Geological heritage is a wide category, and it embraces exceptional geological objects insitu (so-called -geositesll) and ex-situ (specimens in museum collections) (Wimbledon \& Smith-Meyer, 2012; Gray, 2013; Prosser, 2013; Ruban, 2013). However, it would be wrong to limit the geological heritage to the only geological objects. In fact, this category includes also cultural items with haritage value that is (or may be) partly determined by their geological importance 9cf.hose, 200; Migon, 2009; Neches \& Erdeli, 2014). Morover, the geological experience is tied closely to the cultural experience (Tang, 2000; Goudie, 2002; Panizza \& Piacente, 2009; Gordon, 2012; Gray, 2013; Lubova et al., 2013; Neches \& Erdeli, 2014). 
By example of Petra (Jordan), Migon (2009) demonstrated that the well-known UNESCO World Heritage Sites of cultural importance may also have geological heritage value. Its international geological heritage value is evident because of the above-mentioned huge size of the entire cave ensemble. The cave excavation is a very peculiar example of the geological/geomorphological activity of the man, because it differs from the types of this activity (mining, quarrying, etc.) that are commonly mentioned in discussions of the anthropogenic influences on the geological environment (e.g., Goudie, 2013).

\section{METHODOLOGY}

This study pledges several contributions to the existing body of knowledge. From a theoretical/academic perspective, this study establishes a theoretical framework that entails the geotourism and archaeology. Research in this field is useful in developing tourism in and around the karst area as well as geotourism areas where archaeo sites exists. All research work is an exploratory research which follows a case study approach. Though the region is surrounded by beautiful landscapes and so nature lover tourism could also be suggested. It has an excellent potential for further tourism development which is yet to be explored.

Successful management of archaeotourism depends upon the various invested parties developing a shared understanding of what is at stake and how goals will be met (Deacon 2006:380). It is particularly important that local residents be included in these discussions, regardless of the genealogical connection they have with the original occupants of the site. When the local people do not retain the right to develop their own interests for the tourist market, and are instead subjected to top-down initiatives, their communities are likely to suffer (Mitchell and Reid 2001).

\section{LITERATURE REVIEW}

A. Geotourism

Geotourism as form of alternative tourism' is a recent development Newsome et al. (2012) describe geotourism as ..."geologically focused environmentally educative... and fostering local community eliefsll. Geotourism typically takes place in 'geoparks' - areas that can comprise of one or more national parks, UNESCO World Heritage Sites, multiple administrative units or even multiple national units-brought together by a common geological theme (UNESCO, 2010). Initially geotourism was seen as a special type of tourism strictly based on the geological features (often termed geoheritage) of a given destination (Hose, 1995) but the concept gradually grew to encompass various landscape level features, processes, social and cultural involvement with nature and traditional interpretation of phenomena (Gray, 2013). Gray (2013) and Prosser (2013) have emphasized that geotourism must be careful of visitor impacts on geological heritage, and must address the issue of conserving geoheriateg for future generations.

\section{B. Archaeotourism}

Archaeological tourism (sometimes labeled "archaeotourism") is travel that focuses on visiting and experiencing ancient sites and historical places. The motivating forces behind archaeological tourism are a passion for the past and an interest in learning about the ancient or historical cultures that inhabited the area being visited.

"Archaeotourists" are also attracted y the exotic (and often hard to access) nature of the locations in which many archaeological sites are found and often desire unique experiences. Archaeological tourism may include visits to museums, places of historical significance, historically and archaeologically focused parks, and even attendance at traditional dances, festivals, and other events. While archaeological tourism is not new, its scale and scope have grown dramatically in recent years. Hundreds of thousands of tourists now visit archaeological sites annually and archaeological tourism has become a lucrative business. Archaeological 
tourism is often incorporated into the larger fields of ecological tourism, geotourism, and heritage tourism. Many countries offer combinations that allow the visitor to enjoy a regions natural and cultural wonders. Archaeological tourism raises awareness of our shared cultural heritage and encourages people to visit archaeological sites and historical places, but also subjects these precious resources to increased stress. Currently, the growth in tourism to archaeological sites has not been counterbalanced by appropriate revisions to guidelines and laws that mandate "good practices" for visiting sites. This largely unregulated tourism has led to the deterioration and destruction of sites. In some cases local authorities have been forced to close the sites to visitors and promote them in other ways including, as at Altamira in Spain, the creation of exact replicas of the site.

The scope of archaeological and historical tourism has grown dramatically in recent years. It is often incorporated into the field of ecological tourism, geo-tourism and heritage tourism.

Archaeological and historical tourism emerges as one of the most lucrative business worldwide as a large number of tourists now visit archaeological and historical sites annually. The motivating forces behind archaeological and historical tourism are a passion for the past and an interest in learning about the ancient or historical cultures that inhabited the area being visited. People are fascinated with ancient and historical remains.

Archaeological and historical tourism let visitors experience the past and allows them to share the thrill of discovery.

'Archaeo-tourists' are also attracted y the exotic (and often hard to access) nature of the locations in which many archaeological sites are found, as they desire unique experiences.

Archeological and historical tourism is also an education and research based tourism. The, sometimes inaccessible, nature and history of archaeological sites often adds to the sense of adventure and knowledge. It may be a means for tourists to satisfy their curiosity regarding ancient sites or it may be for the purpose of educating tourists who may be students and scholars.

By archaeotourism we mean the visitation of archaeological sites as part of one's tourist activities As such it lies at the intersection of heritage preservation and cultural tourism, which is capturing an everincreasing share of tourist dollars (Wurz and van der Merwe, 2005). The increasing popularity of archaeotourism means that underdeveloped archaeological sites may be at risk from tourism entrepreneurs who lack conservation skills (Wurz and ven der Merwe, 2005:12).

Archaeological tourism can, and does, play an important role in the struggle to preserves the heritage. It helps to educate the general populace about past cultures and modern science. It builds public support for preservation initiatives. It develops important new economic and political allies. All of us that care about our heritage should double our efforts to promote new archaeological parks and museums. Archaeological tourism is very educational, and it is fun.

The Benefits of Locally Directed Tourism Initiatives The outcomes of archaeotourism are largely a matter of how well initiatives are handled (Pinter, 2003), and rely in large part on the design of the project and involvement of key stakeholders. To begin with, the local community may or may not have a deep-seeded investment in the preservation of their heritage. In many developing countries, the majority of destruction caused to heritage sites is by locals due to "indifference, ignorance, or commercial avarice\| (Crosby, 2002:365). We do not wish to give the impression that people in such countries are indifferent or ignorant; rather, we recognize that in many circumstances, economic concerns take priority over academic pursuits. In such a scenario, educating local people about the value of archaeological material is important (Crosby, 2002:365), but education alone will be too little effect if they do not feel the benefits at a personal level. Some of these benefits may, and should, be financial when tourists pay to visit the sites. However, there are also nonmonetary benefits to be gained including an increased sense of self-efficacy 
and empowerment. Like any applied anthropology project, developing a site for archaeotourism should take into consideration the needs of the local community and the effects our work has on that community (Pyburn, 2009; Pyburn and Wilk, 1995).

\section{RESULT AND DISCUSSION}

The existing of pre-historic caves in Bantimurung Bulusaraung National Park is a gift that has a high value for science and education, but its growth as tourist attraction is not fast as its geological attraction. According to the primary data that was collected by researcher, $64.6 \%$ visitors who came to Bantimurung Bulusaraung National Park for recreational activities, $17.3 \%$ for research purposes and the rest $18.1 \%$ for adventures purposes like caving and rock climbing. Research purposes including visiting pre-historic caves. From the percentage of $17.3 \%$, only $4.8 \%$ who really took a research in pre-historic caves. It means that visitors who came to pre-historic were not mainly for tourism activities. Although the caves are located in the national park, the management is not under the national park but under the heritage site preservation board (BPCB), an unit under The Ministry of Education and Culture. The main task of the board is to protect and preserve the historical sites. BPCB has opened the caves for public but it's not really sold as a tourist attraction The caves should attract visitors to learn and encourage people curiosity about pre-historic life in this area, ut it's not happened That condition is very opposite with national park did to develop their potentiality as a tourist destination. Most visitors, especially domestic visitors only pass through the pre-historic caves when they visit this area.

Eventhough BPCB has protect and preserve the pre-historical caves, but the fact those caves are facing a serious danger. Lack of financial makes BPCB has difficulties to maintain the existing pre-historic paintings. Many of those paintings vanish because of natural process and no efforts are taken by the board.

Tourism is expected to be the tools of protection and preservation itself. The value of the caves must be used as education, research and recreation. Collaboration and coordination need to be done because the national park has a good management in tourism and the archaeology need to merge into geotourism development that is taken by national park. There are actions to collaborate the tourism development between the two boards consist of:

A. Establish Geotourism Management Board Until today, The Heritage Site Preservation Board (BPCB) is too focus on the protection and preservation of the pre-historic caves although the reality it is not really protected and preserved. The lack of attention from the government made the caves in highly danger. Everyone can enter the cave and touch the paintings. Lack of financial support also made the caves just like a death museum.

Collaboration with national park is a good solution to solve the management program. The collaboration is in tourism collaboration program. National park has many experiences in tourism development in its area. So the archaeotourism can be developed and promoted together with geotourism.

B. Integrating Archaeotourism with Geotourism through Geotrails/Geotrek With archaeotourism visitors could learn and study about the pre-historic life and understand the importance of the existing of the pre-historic and its paintings. Geotrails or geotrek is an activity that is usually used to bring visitors to take a tour around the geo-heritage or archaeological sites. Along the geotrail visitors will get some explanation related to sites that are visited.

C. Interpretation Facilities and Services

The weakness of geo-heritage and archaeological sites in this area is the lack of interpretation facilities and services. No one has ability to interpret the unique places in the area, especially for prehistoric caves. Every cave has a cave keeper each ut they don't know how to interpret the caves. Interpretation panels that exist in some cave could not give deep understanding to visitors. 
The development of interpretation facilities and services both personal and non-personal need to be developed.

D. Local Community Involvement Through Local Tourism Group

Local community is the main actor in successful of tourism development in this area. Their involvement will support the sustainability of the resources. It is important to empower the locals to be involved and give them benefits.

\section{CONCLUSION}

Integration between national park and The Heritage Sites Preservation Board is an important thing to develop archaeotourism in Bantimurung Bulusaraung National Park. The archaeological resources must be joined to geotourism development in order to keep maintain the high valuable pre-historic caves. Through tourism, the archaeological resources can get many benefits, both financially and protection and preservation of the heritage sites. It needs the awareness of the Heritage Sites Preservation Board to merge to the national park management to encourage the archaeological sites as a tourist attraction.

Theoretically, archaeotourism is under the geotourism concept and the collaboration between the two managements will encourage the tourism development in this area. There are many benefits that could be taken if the collaboration happened. The benefits not only for the national park and BPCB buat also for local community and also the sustain of the heritage sites and it will be more useful for education, learning and increased to local communities well-being.

\section{IMPLICATIONS FOR FUTURE RESEARCH}

There huge tourism potential to be studied in Bantimurung Bulusaraung National Park for future researcher. It is a challenge for another researcher to save heritage sites in this place through tourism. Through this paper people can get some descriptions related to the tourism condition in this area especially the archaeotourism that never a good attention than geotourism.

\section{ACKNOWLEDGEMENT}

- The Management of Bantimurung Bulusaraung National Park

- People of Belae Village who always accompany me

\section{REFERENCES:}

(1) Crosby, A. 2002. Archaeology and vanua development in Fiji. World Archaeology 34:363-378.Darvill, T., (1996),

Prehistoric Britain from the air. A study of space, time and society, Cambridge University Press, Cambridge, p. 268.

(2) Deacon, J. 2006. Rock art conservation and tourism. Journal of Archaeological Method 13:379-399.

(3) Gordon, J.E. (2012). Rediscovering a Sense of Wonder: Geoheritage, Geotourism and Cultural Landscape Experiences. Geoheritage, 4: 65-77.

(4) Goudie, A. (2002). Aesthetics and relevance in geomorphological outreach. Geomor- phology, 47: 245-249.

(5) Gray, M. (2013). Geodiversity: Valuing and conserving abiotic nature. WileyBlack- well, Chichester, 495 pp.

(6) Hose, T.A. \& Vasiiljevica (2012) Defining the nature and purpose of modern geotourism with particular reference to the United Kingdom and south-east Europe. Geoheritage, 4: 25-43.

(7) Lubova, K.A., Zayats, P.P., Ruban, D.A. \& Tiess, G. (2013). Megaclasts in geocon servation: sedimentological questions, anthropogenic influence, and geotour ism

(8) Migon, P (2009). Geomorhosites and the World Heritage list of UNESCO. In: Reynard, E, Coratza, P. \& RegoliniBissig, G. (Eds). Geomorphosites. F. Pfeil, Munchen, pp.119-130.

(9) Mitchell, R.E. and D.G. Reid 2001. Community integration: Island tourism in Peru. Annals of Tourism Research 28:113139.

(10) Neche I -M. \& Erdeli, G. (2014). Geolandscapes and Geotourism: Intergrating Nature and Culture in the Bucegi Mountains of Romania. Landscape Research, doi: 10.1080/01426397.2014.939616. 
(11) Newsome, David, Dowling, Ross and Leung, Yu-Fai, 2012. The Nature and Management of Geotourism: A Case Study of Two Established Iconic Geotourism Destinations. Tourism

Management Perspectives 2-3 (2012) 19-27. Nica, M., Schuster, C., Zorzoliu, T., (1995), Archaeological research in Gumelnita- alcuta's tell from

Draganesti-Olt, Archaeological Research in Northern Tracian Area, p. 9-20.

(12)Panizza, M. \& Piacente, S. (2009). Cultural geomorphology and geodiversity. In: Reynard, E., Coratza, P. \& Regolini-Bis-sig,G.(Eds.).

Geomorphosites feil nchen pp 35-48.

(13)Pinter, T.L. 2003. Heritage Tourism and Archaeology: Critical Issues. The SAA Archaeological Record 5. Prosser, C.D. (2013). Our rich and varied geoconservation portfolio: the foundation for the future. Proceedings of the Geologists' Association 4 568-580.

(14) Pyburn, K.A. 2009. Engaged archaeology: Whose community? Which public? In Global Public Archaeology, edited by A. Matsuda and K. Okamura, pp. 29-41. Springer, New York.

(15)Pyburn, K.A. and R.R. Wilk 1995. Responsible archaeology is applied anthropology. In Ethics in American Archaeology, edited by M.J. Lynott and A. Wylie, pp. 78-83. Society for American Archaeology, Washington, D.C. Reynolds, P., J., (1979), The Butser Ancient Farm Demonstration Area, East Meon Publisher, Hampshire, pp. 20.

(16) Ruban, D.A. \& Kuo, I. (2010). Essentials of geological heritage site (geosite) management: a conceptual assessment of interests and conflicts. Natura Nascosta, 41: 16-31.

(17) Tang, C.M. (2000). Ugly Fossil Syndrome. Palaios, 15: 175-176.

(18)UNESCO, 2010. Global Geoparks Network. Paris: Division of Ecological and Earth Sciences, UNESCO.Valeanu, Cucuteni-Citadel. Archaeological monography, Piatra Neamt, p. 337-351.
(19) Wimbledon, W.A.P. \& Smith-Meyer, S. (Eds.) (2012). Geoheritage in Europe and its conservation. ProGEO, Oslo, 405 pp.

(20)Wurz, S. and J.H. van der Merwe 2005. Gauging site sensitivity for sustainable archaeotourism in the Western Cape Province of South Africa. The South African Archaeological Bulletin 60:1019. 